\title{
Aerosol Refill
}

National Cancer Institute

\section{Source}

National Cancer Institute. Aerosol Refill. NCI Thesaurus. Code C68933.

A container of medication intended to refill an aerosol dispenser. 